\title{
Chapter 10 \\ Seeking Pathways Towards Improved Environmental Governance of the Baltic Sea
}

\author{
Michael Gilek and Mikael Karlsson
}

\begin{abstract}
Governing marine environments is a highly complex and challenging enterprise. This applies particularly to the heavily exploited Baltic Sea for which despite extensive governance arrangements and a substantial scientific knowledge base, it is unlikely that the policy objective of 'good environmental status' is reached. Based on a review of governance arrangements linked to five large-scale environmental issues (eutrophication, overfishing, invasive alien species, chemical pollution and oil spills from shipping), this chapter aims to identify pathways and concrete ideas for institutional reform that may improve goal fulfilment. The results show that governance challenges differ substantially between environmental issues, implying a need for case-specific management reforms. For example, coping with extreme uncertainty is a key challenge in the chemical pollution case, whereas it seems more pertinent in the eutrophication case to address the complexity of nutrient pollution sources by adapting objectives and measures amongst sectoral policies to be in line with environmental ones. Furthermore, cross-case comparisons reveal a set of common vital functions (i.e. coordination, integration, interdisciplinarity, precaution, deliberation, communication and adaptability) that are needed in order to facilitate effective and efficient environmental governance in the long term. To promote these functions in Baltic Sea environmental governance, the chapter suggests pathways and institutional reforms aimed at improving multilevel and multisectoral integration, science-policy interactions and stakeholder participation. To further develop these ideas, it is proposed amongst other things that priority is given to setting up an international 'Baltic Sea Policy Review Mechanism', formed by cross-body and cross-stakeholder participation.
\end{abstract}

Keywords Ecosystem approach to management $\bullet$ Marine policy $\bullet$ Environmental policy integration $\bullet$ Science-policy interactions $\bullet$ Stakeholder participation

\footnotetext{
M. Gilek $(\bowtie) \bullet$ M. Karlsson

School of Natural Sciences, Technology and Environmental Studies,

Södertörn University, 14189 Huddinge, Sweden

e-mail: michael.gilek@sh.se; mikael.karlsson@2050.se
} 


\subsection{Introduction}

The aims of this book and the underlying research ${ }^{1}$ have been to achieve a better and more comprehensive understanding of the complex structures and processes associated with the governance of the Baltic Sea environment and, based on this, to explore problems and opportunities when trying to cope with the identified key governance challenges (Gilek et al. 2015b). We addressed these aims by characterising the problems and risks and by analysing the governance structures, processes and key challenges associated with five large-scale environmental problems and risks in the Baltic Sea: eutrophication, overfishing, invasive alien species, chemical pollution and oil spills from shipping (Hassler 2016; Karlsson and Gilek 2016; Karlsson et al. 2016; Sellke et al. 2016; Smolarz et al. 2016). Based on these case studies, we subsequently explored the key findings in a cross-case analysis of three important dimensions of primary concern for environmental governance: multilevel and multisectoral structures (Boström et al. 2016), assessment-management processes and interactions (Linke et al. 2016) and stakeholder participation and communication (Jönsson et al. 2016). In each of these eight studies, a number of ideas were already identified on how to potentially develop and improve Baltic Sea governance.

In this final chapter, we attempt to take the case and cross-case conclusions further and seek to identify broader pathways, as well as concrete institutional reforms and strategies that we consider could improve environmental governance structures and processes in the Baltic Sea region (BSR). Clearly, these are formidable tasks, since marine environmental governance often is characterised by multiple and potentially conflicting interests (e.g. fisheries, shipping, recreation and conservation), combined with complex ecosystems and multifaceted governance structures and interactions at local, national and international levels in both the public and private spheres. As a consequence, integrated environmental governance of a regional sea like the Baltic Sea has been considered a 'wicked' problem where problem perceptions amongst stakeholders, sectors and countries usually are contested and management responses mostly less than ideal (cf. Gilek et al. 2015a; Jentoft and Chuenpagdee 2009). However, even though this insight initially led us to adopt a quite 'modest' approach by elaborating ideas for long-term structural and processual reforms based on reflexive thinking (Boström et al. 2016), we believe that the severity and urgency of environmental problems and governance shortcomings in the Baltic Sea is a reason to also attempt to develop proposals for concrete and more directly applicable reform measures. In trying to suggest concrete improvements, we approach it humbly by inviting others to scrutinise and debate our proposals. Hopefully, this will stimulate a constructive process resulting in

\footnotetext{
${ }^{1}$ This edited volume presents the findings of the research projects RISKGOV (Environmental Risk Governance of the Baltic Sea) and COOP (Cooperating for Sustainable Marine Governance), which were international interdisciplinary research projects focused on understanding practices and challenges for environmental governance of the Baltic Sea. See, e.g. www.sh.se/riskgov
} 
increasingly concrete and well-crafted measures and strategies for improving the governance of the Baltic Sea environment.

Hence, the logic of this concluding chapter is to, based on a summary of key findings in the individual case studies (Sect. 10.2) and cross-case analyses (Sect. 10.3), venture into developing concrete ideas for how environmental governance of the Baltic Sea potentially could be improved based on an identification of 'root problems'. Finally, we summarise key conclusions and recommendations (Sect. 10.4).

\subsection{Findings in the Five Individual Case Studies}

The five in-depth case studies were identified amongst a set of regional issues that were prioritised in Baltic Sea environmental governance, based on the severity and scope of the associated environmental problems and risks. In Table 10.1, the various problems and risks and their scope, as well as the broad governance patterns, are summarised. As can be seen, the problems are often severe and large scale. Numerous studies have shown that the Baltic Sea is amongst the most disturbed seas worldwide (e.g. HELCOM 2010). In response, the population in the nine countries bordering the Baltic Sea has expressed in monetary terms a willingness to pay nearly 4 billion annually (Baltic Stern 2013) for reducing eutrophication by fulfilling the Baltic Sea Action Plan (HELCOM 2007). Regarding governance patterns, the table shows that the regional level - the EU as well as HELCOM - is nearly always of highest importance, even if local, national and global dimensions play central roles in some of the cases.

Furthermore, it is obvious that the characteristics of the five cases often differ substantially in terms of the complexity of causes and the degree of scientific uncertainty and sociopolitical controversy, as illustrated in Table 10.2. This fact enabled interesting comparisons of governance structures and processes under various conditions.

In general, with the oil case being the main exception, various degrees of more or less high uncertainty and disagreement characterise the cases (Table 10.2). Considering current ambitions to implement the ecosystem approach to management (EAM), implying a need to govern various risks in one and the same ecosystem simultaneously (cf. Boström et al. 2016), the complexity increases even more, due to the various feedback mechanisms involved (remembering also that the impact of climate change will add another complex dimension in the coming decades). In spite of this, a number of governance strategies and tools that can be improved in each of the cases have been identified in the five case study chapters in the book. In the next section, these will be compared and characterised.

In the case of oil discharges, it can generally be concluded that much of the needed governance structures and frameworks are in place. IMO acts as a 'global hub', with the EU as a strong enforcer and HELCOM as a catalyst (Hassler 2016). The complexity of sources is comparatively limited and neither uncertainty nor 
Table 10.1 Summary of identified environmental problems and risks, scope and governance patterns in the five case studies of environmental governance in the Baltic Sea

\begin{tabular}{|c|c|c|c|}
\hline & $\begin{array}{l}\text { Identified problems } \\
\text { and risks }\end{array}$ & Scope & Governance patterns \\
\hline Eutrophication $^{\mathrm{a}}$ & $\begin{array}{l}\text { Hypoxia, algae } \\
\text { blooms, etc. leading to } \\
\text { potentially severe } \\
\text { ecosystem disturbances } \\
\text { and economic losses }\end{array}$ & $\begin{array}{l}\text { Essentially } \\
\text { regional. Different } \\
\text { marine sub-regions } \\
\text { unequally affected }\end{array}$ & $\begin{array}{l}\text { National governments, } \\
\text { EU and HELCOM main } \\
\text { actors. Contradictions } \\
\text { between CAP and } \\
\text { environmental directives }\end{array}$ \\
\hline Overfishing $^{\mathrm{b}}$ & $\begin{array}{l}\text { Decreased stocks, } \\
\text { disturbances on } \\
\text { ecosystems and risk of } \\
\text { extinction of stocks. } \\
\text { Socioeconomic } \\
\text { consequences }\end{array}$ & $\begin{array}{l}\text { Primarily regional, } \\
\text { but sub-regional } \\
\text { genetic variations } \\
\text { cause some local } \\
\text { differences }\end{array}$ & $\begin{array}{l}\text { EU, often exclusive, } \\
\text { competence. ICES plays } \\
\text { important role. RACs } \\
\text { attempt to decentralise } \\
\text { and improve stakeholder } \\
\text { involvement }\end{array}$ \\
\hline $\begin{array}{l}\text { Invasive alien } \\
\text { species }^{\mathrm{c}}\end{array}$ & $\begin{array}{l}\text { Impact on biodiversity, } \\
\text { potentially severe } \\
\text { effects on ecosystem } \\
\text { levels; economic losses }\end{array}$ & $\begin{array}{l}\text { Global, as ballast } \\
\text { water from marine } \\
\text { shipping is the } \\
\text { main vehicle of } \\
\text { entry }\end{array}$ & $\begin{array}{l}\text { Structures have been } \\
\text { weak. Recent regulation } \\
\text { under implementation. A } \\
\text { few stakeholders involved }\end{array}$ \\
\hline $\begin{array}{l}\text { Chemical } \\
\text { pollution }^{\text {d }}\end{array}$ & $\begin{array}{l}\text { Serious impacts on } \\
\text { ecosystems and on } \\
\text { human health. } \\
\text { Halogenated } \\
\text { substances still } \\
\text { problematic and } \\
\text { several emerging risks }\end{array}$ & $\begin{array}{l}\text { Depends on } \\
\text { substance and } \\
\text { source; primarily } \\
\text { regional but also } \\
\text { global product } \\
\text { chains. Often most } \\
\text { serious effects near } \\
\text { the pollution } \\
\text { source }\end{array}$ & $\begin{array}{l}\text { Several global } \\
\text { conventions, but EU } \\
\text { plays the major role. } \\
\text { HELCOM important } \\
\text { complement }\end{array}$ \\
\hline Oil discharges $^{\mathrm{e}}$ & $\begin{array}{l}\text { Large accidents may } \\
\text { severely harm } \\
\text { ecosystems and } \\
\text { socioeconomic } \\
\text { interests; operational } \\
\text { oil spill constant }\end{array}$ & $\begin{array}{l}\text { Essentially global, } \\
\text { as vessels travel } \\
\text { globally. Clean-up } \\
\text { capability local, } \\
\text { national and } \\
\text { sub-regional }\end{array}$ & $\begin{array}{l}\text { IMO plays central role as } \\
\text { an umbrella for global } \\
\text { conventions. HELCOM } \\
\text { initiator. EU may } \\
\text { strengthen enforcement }\end{array}$ \\
\hline
\end{tabular}

Adapted from Hassler et al. (2011)

aKarlsson et al. (2016)

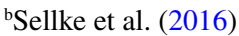

'Smolarz et al. (2016)

${ }^{\mathrm{d}}$ Karlsson and Gilek (2016)

${ }^{\mathrm{e}}$ Hassler (2016)

disagreements seem to impede governance to any significant extent. Risk assessment and risk management are relatively straightforward exercises mostly characterised by monitoring and surveillance on the assessment side and a combination of flag and port state controls in terms of management. Creating incentives for key actors has been important, as have been measures taken by proactive states. We consider that continuing along these lines through EU and HELCOM initiatives 
Table 10.2 Characteristics of five major environmental problems and risks in the Baltic Sea based on individual case studies (see Stirling (2010) for an elaboration of the concept of uncertainty)

\begin{tabular}{|c|c|c|c|}
\hline & $\begin{array}{l}\text { Complexity of } \\
\text { causes }\end{array}$ & $\begin{array}{l}\text { Scientific uncertainty } \\
\text { and scientific } \\
\text { disagreement }\end{array}$ & $\begin{array}{l}\text { Socio-political } \\
\text { controversy }\end{array}$ \\
\hline \multirow[t]{2}{*}{ Eutrophication $^{\mathrm{a}}$} & High & $\begin{array}{l}\text { High uncertainty on } \\
\text { ecosystem effects } \\
\text { and resilience }\end{array}$ & \multirow{2}{*}{$\begin{array}{l}\text { High among stakeholders, } \\
\text { countries, and sectors on } \\
\text { prioritisation of } \\
\text { management actions and } \\
\text { trade-offs among } \\
\text { management objectives }\end{array}$} \\
\hline & $\begin{array}{l}\text { Agriculture, } \\
\text { municipalities, } \\
\text { traffic, maritime } \\
\text { transport, etc. }\end{array}$ & $\begin{array}{l}\text { Some disagreement } \\
\text { on specific } \\
\text { management actions }\end{array}$ & \\
\hline \multirow[t]{2}{*}{ Overfishing $^{\mathrm{b}}$} & Low & $\begin{array}{l}\text { High uncertainty, } \\
\text { especially on } \\
\text { multi-species } \\
\text { management, } \\
\text { ecosystem effects } \\
\text { and resilience }\end{array}$ & \multirow[t]{2}{*}{$\begin{array}{l}\text { Very high on risk framing } \\
\text { (environmental } v s \text {. } \\
\text { socio-economic) and } \\
\text { among stakeholders on } \\
\text { how to cope with } \\
\text { uncertainty }\end{array}$} \\
\hline & $\begin{array}{l}\text { Commercial } \\
\text { fisheries. }\end{array}$ & $\begin{array}{l}\text { Some disagreement } \\
\text { on risk framing }\end{array}$ & \\
\hline \multirow[t]{2}{*}{$\begin{array}{l}\text { Invasive alien } \\
\text { species }^{\mathrm{c}}\end{array}$} & Intermediate & $\begin{array}{l}\text { Extremely high } \\
\text { uncertainty on } \\
\text { outcomes of specific } \\
\text { new introductions }\end{array}$ & \multirow[t]{2}{*}{$\begin{array}{l}\text { Limited with differences } \\
\text { in management priorities } \\
\text { among countries, etc. }\end{array}$} \\
\hline & $\begin{array}{l}\text { Natural and human } \\
\text { sources (e.g. } \\
\text { transports, } \\
\text { aquaculture). }\end{array}$ & $\begin{array}{l}\text { Some disagreement } \\
\text { on risk framing }\end{array}$ & \\
\hline \multirow[t]{2}{*}{ Chemical pollution $^{\mathrm{d}}$} & High & $\begin{array}{l}\text { Extremely high } \\
\text { uncertainty on } \\
\text { sources, long-term } \\
\text { risks and cocktail } \\
\text { effects }\end{array}$ & $\begin{array}{l}\text { High on how to cope with } \\
\text { uncertainty }\end{array}$ \\
\hline & $\begin{array}{l}\text { Point sources, } \\
\text { long-range } \\
\text { transport, products, } \\
\text { etc. }\end{array}$ & $\begin{array}{l}\text { Disagreement on risk } \\
\text { evaluation and on } \\
\text { how to cope with } \\
\text { uncertainty }\end{array}$ & $\begin{array}{l}\text { Intermediate on } \\
\text { cost-benefit trade-offs and } \\
\text { management priorities }\end{array}$ \\
\hline \multirow[t]{2}{*}{ Oil discharges $^{\mathrm{e}}$} & Low & $\begin{array}{l}\text { Intermediate } \\
\text { uncertainty on } \\
\text { long-term effects, } \\
\text { occurrence of } \\
\text { intentional } \\
\text { discharges and } \\
\text { human factor drivers }\end{array}$ & \multirow[t]{2}{*}{$\begin{array}{l}\text { Intermediate on } \\
\text { cost-benefit trade-offs and } \\
\text { management priorities }\end{array}$} \\
\hline & $\begin{array}{l}\text { Mainly marine } \\
\text { transports } \\
\text { (accidental and } \\
\text { operational). }\end{array}$ & Minor disagreement & \\
\hline
\end{tabular}

${ }^{\mathrm{a} K a r l s s o n}$ et al. (2016)

bSellke et al. (2016)

'Smolarz et al. (2016)

${ }^{\mathrm{d}}$ Karlsson and Gilek (2016)

${ }^{\text {e}}$ Hassler (2016) 
could offer a way to further improve governance. In particular, an increased emphasis on human factors as causes of accidents seems warranted, since human error and performance become more important as other causes are reduced.

Concerning fisheries, while the complexity of sources is low, the high uncertainty of some important ecosystem effects in combination with sociopolitical controversies is clearly obstructing governance efforts. One response so far has been to apply a precautionary approach, if not in political decisions on quotas at least in preceding science-based advice. More important are the relatively new arrangements for stakeholder participation (Linke et al. 2016; Sellke et al. 2016). In this case, it seems most important at present to ensure full implementation of the policies in place, which to some extent were recently (2014) renewed in the EU, in order to see if that will be adequate in relation to stated objectives. We consider two dimensions to be particularly important; first, to apply the principle of maximum sustainable yields within the frame of the EAM and the precautionary approach, as well as to phase out discards and subsidies, and, second, to further regionalise decision-making and to improve stakeholder participation.

Similarly, when it comes to invasive alien species (IAS) (Smolarz et al. 2016), recent policies have been adopted (EU 2014). While uncertainty in terms of ecosystem effects of IAS is very high, risk management measures, for example, to better control ballast water, seem well founded and relatively unproblematic to implement, as long as international cooperation works smoothly. Still, if an invasive species has high fitness in the Baltic Sea ecosystem, even quite small implementation deficits might cause large problems, in particular over time. Nevertheless, in our view, a critical point seems to be to ensure an ambitious and broad implementation of the new regulation in its three dimensions of prevention, early warning and rapid response and management. Possibly, this could be achieved if, or when, the IMO Ballast Water Management Convention enters into force.

Regarding chemicals, it is much more difficult than in the other cases to obtain sufficient knowledge. Present risk assessments, that are afflicted with a number of shortcomings, and cocktail effects, amongst other things, are extremely difficult to evaluate (Karlsson and Gilek 2016). There are several science-based methods for coping with uncertainty, for instance, by using precautionary default values for exposure and toxicity when data is missing and by applying alternative decisionmaking criteria, such as maximin criteria (Karlsson 2010; Udovyk and Gilek 2013), but present regulatory frameworks in the EU and the nation states around the Baltic Sea have seldom used such approaches (Linke et al. 2016). Improved environmental risk governance in this case would presume vast regulatory reforms in the EU and amongst parties to the Helsinki Convention. We consider it important, first, to fully reverse the burden of proof for decision-making, meaning, for example, that a producer or user of a substance should show that legal requirements for safety are met so that agencies do not have to prove risks beyond a reasonable doubt. Second, regulatory reforms are needed to better coordinate environmental (e.g. the Marine Strategy Framework Directive, MSFD) and polluter-oriented policy approaches (such as the REACH regulation) (cf. Karlsson and Gilek 2016). 
Finally, in the case of eutrophication, while the basic causes of nutrient leakage are easily identified, the ecosystem and resulting socio-economic effects are far more complex and long-lasting. The difficulty to transform, for example, agricultural production around the Baltic Sea, a dominating source of nutrient leakage, to generally lower levels of nutrient loss, taken together with the strong resistance to do so amongst many farmers and their organisations, makes environmental governance in this case very difficult. This is further complicated by a set of other leakage sources and ambiguity concerning which measures would be most cost effective. Present policies in the EU, HELCOM and individual nation states are far from sufficient to steer development steadily towards agreed targets, which points out a need for both immediate policy-making and longer-term deep reform in the sectors contributing to the problems, as well as in society at large. In the near future, as we see it, pricing externalities in line with the polluter pays principle set out in the EU treaty (meaning, e.g. environmental taxes on fertilisers) and reforming subsidies, steering away from incentivising production not compatible with agreed environmental targets, are examples of potential measures. In the longer run, we consider that deep reforms of agricultural systems might be needed, for example, by improved spatial coordination of crop production and husbandry in order to better control flows of nutrients. At the same time, several of these potential reforms may require an increased willingness to pay amongst consumers for environmental measures in food production.

Evidently, the proposals that we have identified above are not described and evaluated in any detail, and before adopting or implementing such policies and processes, potential consequences should be investigated, whether nationally, in the EU or within HELCOM. We believe though that the ideas presented are motivated to such an extent that they will stimulate discussion and further analysis and studies. In the next section, we zoom out from the specific cases and take a look at governance issues on more of a system level.

\subsection{Findings in the Three Cross-Case Studies}

As shown in the previous chapters of this book, the governance structures in BSR are complex and include formal as well as non-formal components (e.g. Boström et al. 2016). The formal governance consists of institutions and regulatory frameworks at supranational, national and local levels.

At the highest level, both the EU and HELCOM are active in marine governance but have different constellations of members, and while their activities overlap, the policies often have diverging legal strengths ${ }^{2}$ and objectives (e.g. concerning improvements in water status) with differences in time plans, approaches (like EAM)

\footnotetext{
${ }^{2}$ In the EU, binding qualified majority decisions are the normal case, whereas decisions in HELCOM usually presume unanimity and are nonbinding. EU decisions are thus likely to be implemented nationally to a much greater extent than decisions under the Helsinki Convention.
} 
and measures for implementation. The international policies in place also span different sectors, but the mechanisms for coordinating them vary and are far from sufficiently developed as, for example, clearly illustrated in the EU Strategy for BSR (EUSBSR) and the HELCOM Baltic Sea Action Plan (BSAP) relating to, for example, eutrophication (Karlsson et al. 2016). A parallel situation with sectors' cleavages and tensions (e.g. between environmental protection on the one hand and the use of natural resources on the other) often exists at the national and local levels. The prospects for radical multilevel and multisectoral coordination and collaboration in the near future are therefore rather small, but it should not be forgotten that vertical and horizontal interactions in some situations take place by 'uploading' HELCOM recommendations into binding EU directives (Gilek et al. 2015a).

Adding to this complexity, the governance institutions and processes have developed rapidly over the years (Boström et al. 2016; Jönsson et al. 2016), recently by including venues for stakeholder participation such as Regional Advisory Councils (RACs) in EU fisheries management (Sellke et al. 2016). What has also developed rapidly is the extent to which nations in the region have put efforts into marine environmental governance, spanning from forerunners to those whose activities were limited until EU membership, with the exception of those who are still lagging behind on implementation.

Moreover, numerous actors and networks operate in non-formal governance structures in the region, carrying out countless projects in the marine governance field (Boström et al. 2016). All in all, the number of possible interactions, both vertically and horizontally, is massive, which not only opens up the possibilities for collaboration and learning, for instance, between sectors (e.g. HELCOM Fisheries/ Agriculture Forums in relation to BSAP implementation) but may also in other contexts impede possibilities to steer developments and bridge various sector interests. Hence, despite dense and highly interactive multilevel and multi-actor governance structures, integration between these is commonly insufficiently developed.

Regarding assessment-management interactions, the Baltic Sea is often referred to as one of the best-investigated seas in the world, which has laid a foundation for generating science-based advice (e.g. HELCOM 2010; Udovyk and Gilek 2013). This has in some instances led to, at least partially, successful management measures, as seen, for example, in HELCOM's identification and management of pollution hotspots and some hazardous chemicals such as PCBs, despite long recovery times from such marine pollution (Karlsson et al. 2011; Karlsson and Gilek 2016).

A mismatch often exists between the more common regional scientific assessments and the frequently used national management strategies and measures (Linke et al. 2016). Moreover, even in situations when assessment and management regimes address the same level, they often focus on diverging policies and organisational requirements (e.g. EU MSFD and HELCOM BSAP), without sufficient coordination (Karlsson et al. 2016). These institutional and other mismatches cause gaps and overlaps between assessment and management, as well as in the operational chain spanning from definition of environmental objectives over environmental assessment and monitoring to implementation of management measures. 
This means that despite some successful exceptions as exemplified above, science-based advice is far from always used effectively in Baltic Sea environmental governance. This is apparent in the cases of eutrophication (Karlsson et al. 2016) and chemicals (Karlsson and Gilek 2016), where HELCOM has established detailed regional assessments based on scientific input, but management measures are nonetheless seldom fully implemented nationally. Furthermore, risk assessments are usually established based on a conventional view of what constitutes appropriate scientific methodologies and knowledge, often overlooking non-standardised data sources, uncertainty and interactions between various risks, as well as the need for interdisciplinary perspectives and stakeholder input (Linke et al. 2016). The latterlack of stakeholder input - might cause worsened sociopolitical controversies, especially in the presence of uncertainty. In particular, it opens up for strong politicisation where scientists without normative transparency engage in political discussions and politicians selectively interpret scientific results (Karlsson et al. 2011; Linke et al. 2016).

Several chapters in the book analyse and discuss communication and stakeholder participation. Both the EU and HELCOM have invested increasingly in this area of environmental governance in recent years, as, for example, seen in HELCOM's BSAP stakeholder conferences and in RACs under the Common Fisheries Policy (Boström et al. 2016; Jönsson et al. 2016; Sellke et al. 2016). To a large extent though, the case studies reveal that participation in Baltic Sea environmental governance is generally regarded as having an instrumental role to serve the requirements of public policy (Boström et al. 2016). It is of course positive if participation, as assumed in this instrumental framing, leads to more efficient and effective environmental governance and higher acceptance of decision-making processes. Still, this instrumental focus on participation may result in the broader democratic values of participation being overlooked (Jönsson et al. 2016). In addition, our findings indicate that regional structures and processes for stakeholder input and critique are often undeveloped or missing, as seen in the chemicals and IAS cases (Linke et al. 2016; Smolarz et al. 2016). Hence, despite ambitions to develop participation in environmental governance and recent developments of, for example, the RAC system in fisheries management, it can be concluded that regional structures and processes for stakeholder inclusion and deliberation generally remain rather undeveloped in BSR.

Finally, there is an obvious lack of widely available supranational communication arenas in the Baltic Sea region, such as a common Baltic news media, which undermines effective environmental communication. Media coverage at the national level, on the other hand, is much more prominent, often making international coverage invisible (Jönsson et al. 2016). This is likely to obstruct opportunities for environmental governance of the Baltic Sea, since the possibility of stakeholders participating in regional societal debates is limited, as is the potential to develop a common regional understanding of environmental challenges and opportunities. In Table 10.3, we summarise the problems we have found to be important in the crosscase analysis, identify specific problem areas and give concrete examples that illuminate our findings better. 


\subsubsection{Conclusions Based on the Three Cross-Case Studies}

In spite of high policy ambitions, many initiatives and efforts made by a wide set of actors and stakeholders, the overall conclusion of the three cross-case studies is that implementation and enforcement generally lag behind in relation to existing objectives for the Baltic marine environment and that this to a significant extent is associated with 'imperfections' in the studied governance structures and processes as outlined above. However, to address the aim of this chapter - to develop more concrete ideas for improvements - it is important to ask whether it is possible to identify any root problems and causes for these implementation deficits.

Based on the specific problems and shortcomings identified in the cross-case comparisons of the focused governance dimensions (multilevel and multisectoral structures, assessment-management interactions and stakeholder communication and participation), it is possible to discern a set of recurring problem areas (Table 10.3). These problem areas have in previous governance research been identified as key governance challenges (Söderström et al. 2015) and have for the purpose of our analysis, given its limitations, been classified as 'root' problems.

In the following discussion, these identified root problems - together with conclusions from the individual cases - provide a basis to formulate broader pathways as well as associated specific ideas about measures and 'institutional reforms' to potentially improve Baltic Sea environmental governance (Table 10.4). In general, we conclude that it is difficult to go much further with regard to adopted environmental targets for the Baltic Sea, without more fundamental changes, i.e. efforts for improvement must consist of something else than 'more of the same'. This is challenging and complex and requires a continuous and adaptive policy-making and transition process. However, despite these challenges, some positive steps have already been taken in line with our proposed pathways, albeit often in rudimentary ways or only in specific cases. Hence, despite difficulties, we do not see the proposed pathways as impossible to embark on more broadly.

It is hardly surprising, looking at the three cross-case governance dimensions focused on in the book, that the root problems differ between governance structures, assessment-management interactions and stakeholder participation (Table 10.4). Still, even though root problems such as 'insufficient coordination and integration' and 'insufficient flexibility and adaptability' were most influential and problematic in the case of governance structures, these problems are also significant and important with regard to other governance dimensions. This means that Table 10.4 should not be seen as an attempt to strictly differentiate between totally different root problems and pathways for the studied governance dimensions. Instead, the table is an attempt to organise our analysis by highlighting key root problems and potential pathways associated with the studied governance dimensions.

This analysis reveals that current multilevel and multisectoral governance structures mainly are hampered by insufficient coordination and integration, as well as insufficient flexibility and adaptability (Table 10.4). In our cross-case analysis, we identified a set of specific ideas that together can promote a pathway for improved 


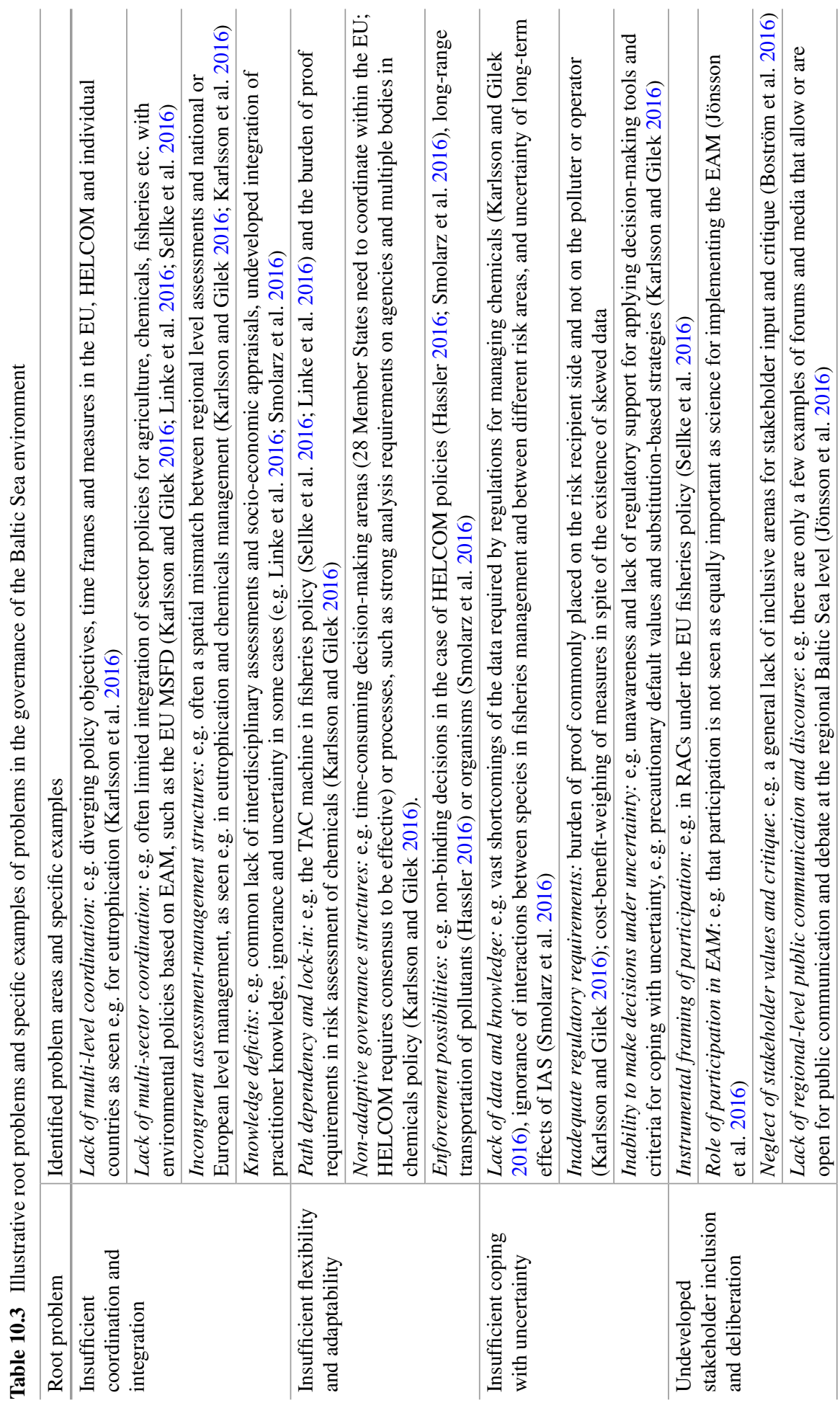


Table 10.4 Identified pathways towards improved environmental governance of the Baltic Sea. Specific ideas for how to promote pathways as well as institutional reform are also indicated (these are further discussed in the text)

\begin{tabular}{|c|c|c|c|}
\hline & $\begin{array}{l}\text { Multi-level and } \\
\text { multi-sector governance } \\
\text { structures }\end{array}$ & $\begin{array}{l}\text { Assessment - } \\
\text { management } \\
\text { interactions }\end{array}$ & $\begin{array}{l}\text { Stakeholder } \\
\text { participation and } \\
\text { communication }\end{array}$ \\
\hline \multirow[t]{2}{*}{$\begin{array}{l}\text { Root } \\
\text { problems }\end{array}$} & $\begin{array}{l}\text { Insufficient coordination } \\
\text { and integration }\end{array}$ & $\begin{array}{l}\text { Insufficient } \\
\text { coordination and } \\
\text { integration }\end{array}$ & \multirow[t]{2}{*}{$\begin{array}{l}\text { Undeveloped } \\
\text { stakeholder inclusion } \\
\text { and deliberation }\end{array}$} \\
\hline & $\begin{array}{l}\text { Insufficient flexibility and } \\
\text { adaptability }\end{array}$ & $\begin{array}{l}\text { Insufficient coping with } \\
\text { uncertainty }\end{array}$ & \\
\hline $\begin{array}{l}\text { Identified } \\
\text { pathways }\end{array}$ & $\begin{array}{l}\text { 'Towards regionally } \\
\text { integrated and reflexive } \\
\text { governance } \\
\text { arrangements' }\end{array}$ & $\begin{array}{l}\text { 'Towards post-normal } \\
\text { science based advice } \\
\text { and precautionary } \\
\text { strategies' }\end{array}$ & $\begin{array}{l}\text { 'Towards inclusive } \\
\text { stakeholder } \\
\text { deliberation' }\end{array}$ \\
\hline \multirow[t]{4}{*}{$\begin{array}{l}\text { Specific } \\
\text { ideas for } \\
\text { promoting } \\
\text { the } \\
\text { identified } \\
\text { broad } \\
\text { pathways }\end{array}$} & $\begin{array}{l}\text { Develop existing } \\
\text { rudimentary synergies } \\
\text { between the EU (e.g. } \\
\text { MSFD) and HELCOM's } \\
\text { (e.g. BSAP) } \\
\text { environmental policies, } \\
\text { for example by } \\
\text { synthesising BSAP and } \\
\text { EUSBSR. Enforcement } \\
\text { can often be improved by } \\
\text { rescaling regional } \\
\text { initiatives to EU } \\
\text { regulations }\end{array}$ & $\begin{array}{l}\text { Explicit requirements } \\
\text { for interdisciplinary, } \\
\text { socio-economic (incl. } \\
\text { cost of no action) } \\
\text { assessments, as well as } \\
\text { stakeholder and } \\
\text { practitioner input }\end{array}$ & $\begin{array}{l}\text { Make provisions for } \\
\text { stakeholder inclusion } \\
\text { and deliberation more } \\
\text { explicit in EAM } \\
\text { implementation, e.g. } \\
\text { linked to } \\
\text { implementation of the } \\
\text { EU MSFD, the } \\
\text { HELCOM BSAP and } \\
\text { the EUSBSR }\end{array}$ \\
\hline & $\begin{array}{l}\text { Reform sector policies } \\
\text { (e.g. CAP, CFP, REACH) } \\
\text { to strengthen interactions } \\
\text { with environmental } \\
\text { policies (e.g. MSFD, } \\
\text { BSAP). Integrative } \\
\text { policies such as MSP } \\
\text { can be important } \\
\text { mechanisms }\end{array}$ & $\begin{array}{l}\text { Explicit requirements } \\
\text { for uncertainty appraisal } \\
\text { and development of } \\
\text { regionally common } \\
\text { guidelines for this }\end{array}$ & $\begin{array}{l}\text { Enhanced efforts to } \\
\text { communicate regional } \\
\text { level environmental } \\
\text { issues and governance } \\
\text { challenges, as well as } \\
\text { environmental values, } \\
\text { services etc. to the } \\
\text { general public }\end{array}$ \\
\hline & \multirow{2}{*}{$\begin{array}{l}\text { Make explicit } \\
\text { requirements for } \\
\text { continuous review and } \\
\text { reform of governance } \\
\text { arrangements based on } \\
\text { key criteria such as } \\
\text { participation, precaution, } \\
\text { polluter pays, adaptive } \\
\text { learning and equity }\end{array}$} & $\begin{array}{l}\text { Regulatory provisions } \\
\text { for changed burden of } \\
\text { proof and other types of } \\
\text { precautionary measures }\end{array}$ & \multirow{2}{*}{$\begin{array}{l}\text { Institutionalise forums } \\
\text { and media for } \\
\text { generating a stronger } \\
\text { Baltic identity, seeking } \\
\text { to ensure that Russia } \\
\text { and Russian } \\
\text { stakeholders are also } \\
\text { stimulated to } \\
\text { participate }\end{array}$} \\
\hline & & $\begin{array}{l}\text { Institutional reforms to } \\
\text { improve the regional } \\
\text { and multi-sector basis } \\
\text { for integrated science- } \\
\text { based advice; } \\
\text { streamlining the } \\
\text { time-consuming system } \\
\text { of analysing and } \\
\text { decision-making bodies }\end{array}$ & \\
\hline
\end{tabular}


Table 10.4 (continued)

\begin{tabular}{l|l|l|l}
\hline & $\begin{array}{l}\text { Multi-level and } \\
\text { multi-sector governance } \\
\text { structures }\end{array}$ & $\begin{array}{l}\text { Assessment - } \\
\text { management } \\
\text { interactions }\end{array}$ & $\begin{array}{l}\text { Stakeholder } \\
\text { participation and } \\
\text { communication }\end{array}$ \\
\hline $\begin{array}{l}\text { Associated } \\
\text { ideas for }\end{array}$ & $\begin{array}{l}\text { Baltic Sea Policy Review } \\
\text { Mechanism }\end{array}$ & $\begin{array}{l}\text { Baltic Sea Science } \\
\text { Panel }\end{array}$ & $\begin{array}{l}\text { Regional Marine } \\
\text { Advisory Panel }\end{array}$ \\
\cline { 2 - 4 } $\begin{array}{l}\text { reform to } \\
\text { develop } \\
\text { required } \\
\text { governance } \\
\text { functions }\end{array}$ & $\begin{array}{l}\text { For recurring review and } \\
\text { reflection on multi-level, } \\
\text { multi-sector and } \\
\text { multi-actor governance } \\
\text { arrangements }\end{array}$ & $\begin{array}{l}\text { To serve as a regional } \\
\text { interdisciplinary source } \\
\text { for assessments, } \\
\text { science-based advice } \\
\text { and guidelines, e.g. as } \\
\text { an interdisciplinary } \\
\text { regional section under } \\
\text { ICES }\end{array}$ & $\begin{array}{l}\text { To support e.g. BSAP, } \\
\text { MSFD, MSP with } \\
\text { stakeholder advice - } \\
\text { e.g. organised in } \\
\text { sectoral sections and a } \\
\text { cross-sectoral forum }\end{array}$ \\
\hline
\end{tabular}

aPost-normal science builds on the acknowledgement of fundamental uncertainties and integration of interdisciplinary and stakeholder knowledge and has been proposed as a necessary form of science-based advice on complex environmental issues (e.g. Funtowicz and Ravetz 1993)

${ }^{\mathrm{b}}$ Marine Spatial Planning

environmental governance. Taken together we see possibilities that these measures and reforms could promote a pathway towards regionally integrated and reflexive governance arrangements.

First, based on previous literature, it is known that there often is a synergetic relationship between the processes of Europeanisation and regionalisation (e.g. in the Baltic Sea region) in marine environmental policy (Gilek et al. 2015a). This can, for example, be illustrated by the mutually reinforcing relationships between the EU MSFD and HELCOM BSAP (Gilek et al. 2015b). We argue that these synergistic multilevel relationships can be strengthened further by coordinating implementation, but moreover by actually adjusting each of these policy schemes so that they address gaps and ineffective overlaps. In addition, coordination is needed with the EU Strategy for BSR, which ideally could serve as a bridging instrument. It would also be highly beneficial to, as far as needed and possible, attempt to 'rescale' regional initiatives from, for example, HELCOM, and make them into binding EU directives or regulations as a means to improve enforcement possibilities in the EU members states around the Baltic Sea.

Second, to improve possibilities for multisectoral coordination and integration, we see substantial possibilities to reform sectoral policies such as CAP, CFP and REACH in order to strengthen their interactions with environmental policies, such as WFD, MSFD and BSAP. Without overlooking strong stakeholder interests striving to preserve as much control over policies as possible, we argue that coordination would be more of a win-win exercise than non-coordination, since present sector policies allow or even subsidise a development that society then tries to govern by imposing environmental policies in terms of laws and taxation. Basically, such insufficient multisectoral coordination creates a situation of conflictual incentives and suboptimal measures for farmers, fishermen, etc., without any long-term safety from either an environmental or market point of view. Well-coordinated frameworks 
would be more rewarding and easier to deal with from multiple, including environmental and economic, points of views. Here, we see the current ambitions and initiatives to develop integrative policies in the form of marine spatial planning as a potentially important step to improve multisectoral integration in the governance of Baltic marine territory and resources (e.g. Gilek et al. 2015a). However, MSP is at an early stage of development, especially in relation to transboundary governance challenges, such as in the case of the Baltic Sea, which means that substantial efforts are needed in terms of both research and practice in the coming years to develop ideas, processes and approaches that could facilitate integrative MSP.

Finally, we argue that marine governance always will be a work in progress, not least considering the commonly evolving character of natural systems and factors such as policy aims, environmental status and values, stakeholder interests and stakes (cf. Gilek et al. 2015a). This means that marine governance arrangements and aims will continuously need to be reviewed and reformed in a reflexive manner to adapt to new contexts and challenges. In order to do so, we argue that there is a need to set up an institution of one type or another to regularly review and reform Baltic environmental governance - a 'Baltic Sea Policy Review Mechanism' (Table 10.4). It should be further investigated how this 'mechanism' could be achieved - for example, if it should be part of existing institutions or not, if it should be a temporary or standing body and if governments should play a role themselves or rather appoint a more independent top-level forum. In the further development of this mechanism, models in other areas could be analysed, for instance, the GOC on oceans, the IPCP on chemicals, the IPCC on climate and the IPBES on biodiversity, which all have different aims, compositions, functions and ways of operation. ${ }^{3}$

Regarding assessment-management interactions, we have concluded that there are insufficient coordination and integration and insufficient handling of uncertainty. We have also identified a need to acknowledge various forms of incertitude (Table 10.4; cf. Linke et al. 2016), for example, by applying interdisciplinary assessment and management approaches and methods from post-normal science studies, as well as science-based precautionary management strategies.

First, it is important to set up assessment strategies that support and develop interdisciplinary approaches and incorporate laymen's and stakeholder's practical knowledge. Besides improved natural science data and studies, knowledge directly needed from a management point of view is considered important, not least in terms of socio-economic data on the so-called 'cost of no action' (the Baltic Stern project is a good start in this respect, cf. Baltic Stern 2013).

Second, explicit regional requirements and guidelines for uncertainty appraisal need to be developed. In addition, regulatory provisions are needed to cope with uncertainty by changing the burden of proof and imposing other types of precautionary measures (cf. Karlsson 2005; Udovyk and Gilek 2013). One important measure would be to allow science-based precautionary default values when data is

\footnotetext{
${ }^{3}$ See http://www.globaloceancommission.org/about-the-commission/mandate/, http://www.ipcp. ch/about-ipcp, http://www.ipcc.ch/organization/organization.shtml, http://www.ipbes.net/aboutipbes.html
} 
missing, for example, by classifying substances in groups according to so-called worst-case assumptions or by assuming that exotic species are always invasive unless scientific studies reasonably indicate the opposite (Cooney and Dickson 2005; Karlsson 2010; Sandin and Hansson 2002). In contrast with the common decision-making approach to weigh costs and benefits, there are good reasons to instead, or as a complement, apply the maximin criteria to minimise the probability of the worst-case scenario, since data on costs and benefits often are missing or uncertain (cf. Hansson 1997). In some cases, this has to be institutionalised as hard regulation, but in other cases soft policy and regulatory approaches might be possible and even preferable as a testing ground where proactive stakeholders can show a way forward that others can eventually follow. A combination of soft and hard regulations can often be rewarding (cf. Hassler 2016).

Finally, a smoother transfer of data and knowledge from assessment to management is needed, hand in hand with a more holistic approach in the design of decisionmaking bodies. This relates to improved sectoral integration of science-based advice (e.g. eutrophication and fisheries are interrelated in numerous ways, such as oxygen depletion affecting the survival of cod eggs) and the need for more streamlined management systems. Examples of the latter are the multiple and timeconsuming processes of integrating scientific data on hazardous chemicals in the REACH regulatory system, where long-lasting negotiations and interpretation exercises have often replaced an efficient use of new scientific evidence and where arbitrary and normative thresholds place an unreasonably high burden of proof on agencies before decisions can be made (cf. Karlsson 2010).

In order to accomplish these various points in a coordinated and rational manner, we see a need for what could be called a 'Baltic Sea Science Panel', which potentially could be developed as part of the International Council for the Exploration of the Sea (ICES) (Table 10.4).

In the area of stakeholder participation and communication, our critique is that there is an underdeveloped situation in which participation is framed instrumentally. Also there are recurring problems of representation and power (Table 10.4; Boström et al. 2016). In response to this, we have identified several possible initiatives that together could pave the way for a pathway towards inclusive stakeholder deliberation.

First, it is important to make provisions for stakeholder inclusion and deliberation more explicit in EAM implementation, for example, linked to implementation of the EU MSFD, HELCOM BSAP and EUSBSR. Despite recognition of the fundamental role of stakeholder input in the so-called Malawi principles for an ecosystem approach (cf. Hammer 2015), EAM in the Baltic Sea is today primarily framed as being based on the best available scientific knowledge. This is, for example, seen in the HELCOM definition of EAM (cf. Karlsson et al. 2016). We believe that there are strong instrumental (e.g. linked to governability and governance outcomes) and normative arguments (e.g. linked to democratic ideals of just representation) for striving to complement this science-based approach with a stronger focus on developing participatory aspects of EAM (cf. Jönsson et al. 2016). This could 
substantially improve possibilities for improved stakeholder input and advice in the governance of the Baltic marine environment.

Second, we see a substantial need for enhanced efforts to communicate environmental issues and governance challenges, as well as environmental values, services, etc., to the general public in BSR. As an example, Jönsson et al. (2016) mention that environmental communication could be prioritised by HELCOM and national authorities as part of BSAP implementation and that this subsequently could attract the attention of media and thereby reach out to the general public. This could complement and even enhance communication efforts by other actors such as business sector organisations and environmental NGOs. All in all, enhanced regional level environmental communication could turn the Baltic Sea environment into a hopefully somewhat 'hotter' topic in regional public debate and ultimately stimulate wider engagement to participate in proactive discussions on environmental governance (cf. Jönsson et al. 2016).

Finally, there is a need to set up regional forums for stakeholder advice, as well as regional media and communication platforms for generating a stronger Baltic identity that include Russia and Russian stakeholders. It seems unrealistic today to develop an 'all-inclusive' institution for stakeholder advice that involves all stakeholders from all sectors and that integrates stakeholder opinions and critiques of all relevant policy areas. However, we believe that a 'Regional Marine Advisory Panel', supporting, for example, BSAP, MSFD and MSP with stakeholder advice, could be set up by combing sectoral subdivisions with integrating forums (cf. Dreyer and Sellke 2015).

\subsection{Concluding Remarks}

These identified pathways towards improved environmental governance of the Baltic Sea are in need of further analysis and consideration, not least when it comes to how they potentially could interact with each other. Similarly, while a complex reality might seem to call for complex governance structures and processes, overlaps, gaps and counteracting policies are seldom fruitful, and hence we want to caution against creating even more of a governance thicket than today. In this respect, some of our proposals to reform bodies might seem counterproductive. However, while these bodies could fit in or replace current institutions, we want to underline that the seven identified functions - coordination, integration, interdisciplinarity, precaution, deliberation, communication and adaptability - will continue to be the most important aspects that need to be taken into account. Whichever governance set-up that is chosen, these aspects cannot be overlooked, as they largely are today, when striving towards improved governance of the Baltic Sea environment and its natural resources. Undoubtedly, further investigations would be needed on how to structure these - or similar - coordinating bodies so that they really promote the vital governance functions that are strikingly missing or underdeveloped today. To further develop these ideas, we suggest that priority is given to setting up 
the proposed international 'Baltic Sea Policy Review Mechanism' that can be formed by cross-body and cross-stakeholder participation. Whether or not this specific proposal will be realised is less important than the need for fundamental reforms based on the functions and ideas discussed here and in the other chapters of this book if improved environmental governance of the Baltic Sea is to be realised.

Acknowledgements This chapter is based on research undertaken within the research projects RISKGOV 'Environmental Risk Governance of the Baltic Sea' (2009-2015) and COOP 'Cooperating for Sustainable Regional Marine Governance'. RISKGOV involved research teams from Södertörn University in Sweden, Åbo Akademi University in Finland, Dialogik/Stuttgart University in Germany and Gdansk University in Poland. Funding came from the Foundation for Baltic and East European Studies and the European Community's Seventh Framework Programme (2007-2013) under grant agreement no. 217246 made with the joint Baltic Sea research and development programme BONUS, as well as from the German Federal Ministry of Education and Research (BMBF), the Swedish Environmental Protection Agency, the Swedish Research Council FORMAS, the Polish Ministry of Science and Higher Education and the Academy of Finland. We thank these institutions for enabling us to conduct this research. We also thank all participants in the research programmes for providing valuable input.

Open Access This chapter is distributed under the terms of the Creative Commons AttributionNoncommercial 2.5 License (http://creativecommons.org/licenses/by-nc/2.5/) which permits any noncommercial use, distribution, and reproduction in any medium, provided the original author(s) and source are credited.

The images or other third party material in this chapter are included in the work's Creative Commons license, unless indicated otherwise in the credit line; if such material is not included in the work's Creative Commons license and the respective action is not permitted by statutory regulation, users will need to obtain permission from the license holder to duplicate, adapt or reproduce the material.

\section{References}

Baltic Stern, SWAM (Swedish Agency for Marine and Water Management) (2013) The Baltic Sea - our common treasure. Economics of saving the sea. Rapport 2013:4, SWAM

Boström M, Grönholm S, Hassler B (2016) The ecosystem approach to management in Baltic Sea governance: towards increased reflexivity? In: Gilek M et al (eds) Environmental governance of the Baltic Sea. Springer, Dordrecht

Cooney R, Dickson B (eds) (2005) Biodiversity and the precautionary principle. Risk and uncertainty in conservation and sustainable use. Earthscan, London

Dreyer M, Sellke P (2015) The Regional Advisory Councils in European fisheries: an appropriate approach to stakeholder involvement in an EU integrated marine governance? In: Gilek M, Kern K (eds) Governing Europe's marine environment. Europeanization of regional seas or regionalization of EU policies? Ashgate Publishing, Farnham

EU (2014) Regulation (EU) 1143/2014 of the European Parliament and of the Council on the prevention and management of the introduction and spread of invasive alien species. OJ L 317:35-55

Funtowicz S, Ravetz JR (1993) Science for the post-normal age. Futures 25:739-755

Gilek M, Hassler B, Jentoft S (2015a) Marine governance in Europe: problems and opportunities. In: Gilek M, Kern K (eds) Governing Europe's marine environment. Europeanization of regional seas or regionalization of EU policies? Ashgate Publishing, Farnham 
Gilek M, Karlsson M, Udovyk O, Linke S (2015b) Science and policy in the governance of Europe's marine environment - the impact of Europeanization, regionalization and the ecosystem approach to management. In: Gilek M, Kern K (eds) Governing Europe's marine environment. Europeanization of regional seas or regionalization of EU policies? Ashgate Publishing, Farnham

Hammer M (2015) The ecosystem management approach. Implications for marine governance. In: Gilek M, Kern K (eds) Governing Europe's marine environment. Europeanization of regional seas or regionalization of EU policies? Ashgate Publishing, Farnham

Hansson SO (1997) The limits of precaution. Found Sci 2:293-306

Hassler B (2016) Oil spills from shipping: a case study of the governance of accidental hazards and intentional pollution in the Baltic Sea. In: Gilek M et al (eds) Environmental governance of the Baltic Sea. Springer, Dordrecht

Hassler B, Boström M, Grönholm S, Kern K (2011) Environmental risk governance in the Baltic Sea - a comparison among five key areas. RISKGOV report, delivery number 8. Södertörn University, Huddinge, Available from: http://www.sh.se/riskgov

HELCOM (2007) Baltic Sea Action Plan. Adopted at HELCOM Ministerial Meeting, Krakow $15 / 11 / 07$

HELCOM (2010) Ecosystem health of the Baltic Sea 2003-2007: HELCOM initial holistic assessment. Baltic Sea Environmental Proceedings No. 122

Jentoft S, Chuenpagdee R (2009) Fisheries and coastal governance as a wicked problem. Mar Policy 33:553-560

Jönsson AM, Boström M, Dreyer M, Söderström S (2016) Risk communication and the role of the public: towards inclusive environmental governance of the Baltic Sea? In: Gilek M et al (eds) Environmental governance of the Baltic Sea. Springer, Dordrecht

Karlsson M (2005) Managing complex environmental risks for sustainable development: policies for hazardous chemicals and genetically modified organisms. Doctoral thesis, Karlstad University Studies 2005:34. Karlstad University

Karlsson M (2010) The precautionary principle in EU and US chemicals policy: a comparison of industrial chemicals legislation. In: Eriksson J et al (eds) Regulating chemical risks: European and global challenges. Springer, Dordrecht

Karlsson M, Gilek M (2016) Governance of chemicals in the Baltic Sea region: a study of three generations of hazardous substances. In: Gilek M et al (eds) Environmental governance of the Baltic Sea. Springer, Dordrecht

Karlsson M, Gilek M, Udovyk O (2011) Governance of complex socio-environmental risks: the case of hazardous chemicals in the Baltic Sea. Ambio 40:144-157

Karlsson M, Gilek M, Lundberg C (2016) Eutrophication and the ecosystem approach to management: a case study of Baltic Sea environmental governance. In: Gilek $M$ et al (eds) Environmental governance of the Baltic Sea. Springer, Dordrecht

Linke S, Gilek M, Karlsson M (2016) Science-policy interfaces in Baltic Sea environmental governance: towards regional cooperation and management of uncertainty? In: Gilek M et al (eds) Environmental governance of the Baltic Sea. Springer, Dordrecht

Sandin P, Hansson SO (2002) The default value approach to the precautionary principle. Hum Ecol Risk Assess 8:463-471

Sellke P, Dreyer M, Linke S (2016) Fisheries: a case study of Baltic Sea environmental governance. In: Gilek M et al (eds) Environmental governance of the Baltic Sea. Springer, Dordrecht

Smolarz K, Biskup P, Zgrundo A (2016) Biological invasions: a case study of Baltic Sea environmental governance. In: Gilek $M$ et al (eds) Environmental governance of the Baltic Sea. Springer, Dordrecht

Söderström S, Kern K, Boström M, Gilek M (2015) Environmental governance and ecosystem management: avenues for synergies between two approaches. Interdiscip Environ Rev (In press)

Stirling A (2010) Keep it complex. Nature 468:1029-1031

Udovyk O, Gilek M (2013) Coping with uncertainties in science-based advice informing environmental management of the Baltic Sea. Environ Sci Policy 29:12-23 